\title{
Correlation of atmospheric purity index to the diversity of lichens in the Horton Plains National Park, Sri Lanka
}

\author{
R.G.U. Jayalal ${ }^{1}$, O.A. Ileperuma ${ }^{2}$, P. Wolseley ${ }^{3}$, D.S.A. Wijesundara ${ }^{4}$ and \\ V. Karunaratne ${ }^{2, *}$ \\ ${ }^{1}$ Department of Natural Resources, Sabaragamuwa University of Sri Lanka, Belihuloya 70140 \\ Sri Lanka \\ ${ }^{2}$ Department of Chemistry, Faculty of Science, University of Peradeniya, Peradeniya, Sri Lanka \\ ${ }^{3}$ Department of Botany, The Natural History Museum, Cromwell Rd, London SW7 5BD, UK \\ ${ }^{4}$ National Institute of Fundamental Studies, Hantana Road, Kandy, Sri Lanka
}

\section{Received: 03/10/2016; Accepted: 10/05/2017}

\begin{abstract}
Horton Plains National Park (HPNP) has been declared as a world heritage site, because of its unique biodiversity. Die-back of certain areas of this park is widely believed to be due to acidic precursor depositions carried over from other parts of the country and also from neighboring countries. Air pollution data for the two pollutants, $\mathrm{NO}_{2}$ and $\mathrm{SO}_{2}$ were obtained from the passive air sampling method. The data revealed that the concentrations of ambient $\mathrm{NO}_{2}$ and $\mathrm{SO}_{2}$ were very low in the HPNP. The variations of ambient $\mathrm{NO}_{2}$ and $\mathrm{SO}_{2}$ concentrations during the study period showed insignificant positive correlation $(\mathrm{p} \geq 0.05)$ with the rainfall data. Considering the variations of these two pollutants with Relative Humidity and the number of vehicles visiting HPNP, both pollutants had insignificant positive correlation. The Index of Atmospheric Purity (IAP) value obtained for the whole area of the HPNP was 54.22. This value belongs to the quality level 5 which represents the 'very low' pollution level. The results including lichen distribution and air quality data could confirm that the ambient air quality at HPNP is very high. The high diversity of lichens and the minimum levels of air pollutants suggested that the forest health of HPNP is at a favorable level. Therefore, it is essential to maintain at least the current air pollution level of HPNP in order to conserve the forest and its biodiversity.
\end{abstract}

Keywords: Lichen Diversity; Horton Plains; Air Pollution; Sri Lanka.

\section{INTRODUCTION}

Horton Plains National Park of Sri Lanka, a cloud forest, recently designated as a World Heritage Site by UNESCO. Because of the unique climatic and physiographic features, it ranks high among the biodiversity super hotspots within the Western Ghats and Sri Lanka harboring a large number of endemic flora and fauna within its range (World Heritage Report, 2010). HPNP is located about $24 \mathrm{~km}$ south of Nuwara Eliya between latitude $6^{\circ} 47^{\prime}-6^{\circ} 50^{\prime} \mathrm{N}$ and longitudes $80^{\circ} 46^{\prime}-80^{\circ} 51^{\prime} \mathrm{E}$ at an elevation ranging from $1500 \mathrm{~m}$ to $2524 \mathrm{~m}$ Above Sea Level (ASL) with a plateau starting from about 2,100 $\mathrm{m}$ ASL. This is the only montane plain in Sri Lanka with a natural history dating back to pre-historical times (Green, 1990). The unique characteristics of this ecosystem highlight the importance of its conservation. However, the forest die back at HPNP in recent times has initiated a debate regarding air pollution issues at the park.

In one of the rare studies related to the atmospheric pollution at the HPNP, Gunawardena et al. (1998) reported the possibility of acid deposition in the fog which arrives predominantly from the Indian continent and from the western parts of the country where more than $50 \%$ of the vehicle population and the major industries are located. Further, they reported that atmospheric pollution levels in the HPNP may increase due to the trans-boundary pollution from the Indian Sub-continent during the North-East monsoon.

Although chemical analysis to determine the atmospheric purity is important and would derive baseline information, biomonitoring attempts to evaluate the presence of air pollutants are not reported from HPNP. Biomonitoring is a collective term for the techniques where living organisms are used to provide information about both abiotic and biotic components of an 
environment. Biological monitoring of air pollutants can be passive or active. Passive methods involve observing plants growing naturally within the area of interest. Active methods detect the presence of air pollutants by introducing test plants of known genotypes and its response within the study area (Mulgrew and Williams, 2000).

Traditionally, lichens flora have been used for monitoring air pollution from the $1860 \mathrm{~s}$ (Nylander, 1866; James, 1973; Seaward et al., 1981; Garty and Hagemeyer, 1988; Brown, 1984; Sawidis et al., 1995; Nimis et al., 2002; Stamenkovic et al., 2010; Jayalal et al., 2015). Because of the lack of a cuticle and an epidermis, lichens accumulate air borne metals (Olmez et al., 1985), actively uptake anions and adsorb cations and ion exchange ions such as $\mathrm{Na}^{+}$and $\mathrm{Ca}^{2+}$ passively (Nieboer and Richardson, 1981).

The diversity of HPNP lichen flora can use as a tool for biomointoring air pollutant levels at the HPNP (Jayalal et al., 2006). The most recent check list of flowering plants within the HPNP prepared by Wijesundara (2007) indicated 653 species belong to 102 families and 461 genera. However, no extensive collection of lichens have been recorded in the past in HPNP other than Santesson and Moberg who visited Sri Lanka in 1975 and collected about 10 specimens of Thelotremataceae, mostly from the Horton Plains area (Hale, 1981). More recently,many lichen species have been recorded from HPNP (Jayalal et al., 2012; Wijesundara \& Karunaratne, 2015).

According to the past literature and some recent investigations on lichens carried out in Sri Lanka, the numbers of lichen species already recorded from Sri Lanka may exceed 1,000 species (Jayalal et al., 2008). Importantly several new species have been added to the Sri Lankan lichen flora (Orange et al., 2001; Jayalal et al., 2012; Weerakoon et al., 2012). The rich chemical substances and their biological/pharmaceutical activities have made lichens important organisms (Karunaratne et al.,
2005; Kathirgamanathar et al., 2006; Thadhani et al., 2012). Finally, in terms of the soil ecology, phenolic lichen metabolites are known to play siderophore type iron chelating ability (Karunaratne et al., 1992; Jayasinghe et al., 2015), thus affecting soil microbial dynamics.

The objective of this study was firstly to determine the quality of ambient air chemically, by measuring the concentrations of $\mathrm{SO}_{2}$ and $\mathrm{NO}_{2}$, over a period of 12 months, and secondly to correlate the data to biomonitoring of lichens through determining their diversity at HPNP using the Index of Atmospheric Purity (IAP) modeling.

\section{METHODOLOGY}

\section{Climatic parameters}

Climatic parameters such as rainfall, maximum and minimum daily temperature, wind direction and relative humidity during the research period were obtained on a daily basis from the Seetha Eliya Meteorological Station which is located about $10 \mathrm{~km}$ from the sampling sites.

\section{Preparation of air samplers and sampler stands}

Reagents were prepared, using high purity chemicals from Sigma-Aldrich, in small vials immediately prior to the use. Samplers were in house assembled using $25 \mathrm{~mm}$ diameter Teflon rods and were prepared using the method followed by Ileperuma and Abeyratne (2001). The sampler stands were also manufactured inhouse using PVC tubes and plastic plates. Prior to use, all sampler components and glass vials were soaked in a detergent solution to remove contaminants, rinsed thoroughly, dried in an oven and stored in a clean environment.

The coating solution for $\mathrm{NO}_{2}$ was prepared by dissolving $0.44 \mathrm{~g}$ of $\mathrm{NaOH}$ and $3.95 \mathrm{~g}$ of $\mathrm{NaI}$ in $10 \mathrm{ml}$ of water and diluting to $50 \mathrm{ml}$ with methanol. For $\mathrm{SO}_{2}$ determination, the coating solution was prepared by dissolving $0.5 \mathrm{~g}$ of $\mathrm{NaOH}$ in the minimum of water followed by dilution to $50 \mathrm{ml}$ with methanol. 
Table 1: Location characteristics (latitude, longitude and elevation) of the five air sampling points in HPNP.

\begin{tabular}{lccc}
\hline Sampling Site & Latitude & Longitude & Elevation (m) \\
\hline Pattipola Road & $06^{\circ} 50^{\prime} 30.4^{\prime \prime} \mathrm{N}$ & $80^{\circ} 48^{\prime} 45.7^{\prime \prime} \mathrm{E}$ & 2,172 \\
\hline Ohiya Road & $06^{\circ} 48^{\prime} 45.7^{\prime \prime} \mathrm{N}$ & $80^{\circ} 90^{\prime} 11.0^{\prime \prime} \mathrm{E}$ & 2,161 \\
\hline Worlds' End & $06^{\circ} 47^{\prime} 08.1^{\prime \prime} \mathrm{N}$ & $80^{\circ} 47^{\prime} 59.8^{\prime \prime} \mathrm{E}$ & 2,080 \\
\hline $\begin{array}{l}\text { Middle (Car Park area of } \\
\text { HPNP) }\end{array}$ & $06^{\circ} 48^{\prime} 10.0^{\prime \prime} \mathrm{N}$ & $80^{\circ} 48^{\prime} 26.4^{\prime \prime} \mathrm{E}$ & 2,190 \\
\hline Kirigalpotta & $06^{\circ} 47^{\prime} 55.0^{\prime \prime} \mathrm{N}$ & $80^{\circ} 47^{\prime} 46.3^{\prime \prime} \mathrm{E}$ & 2,145 \\
\hline
\end{tabular}

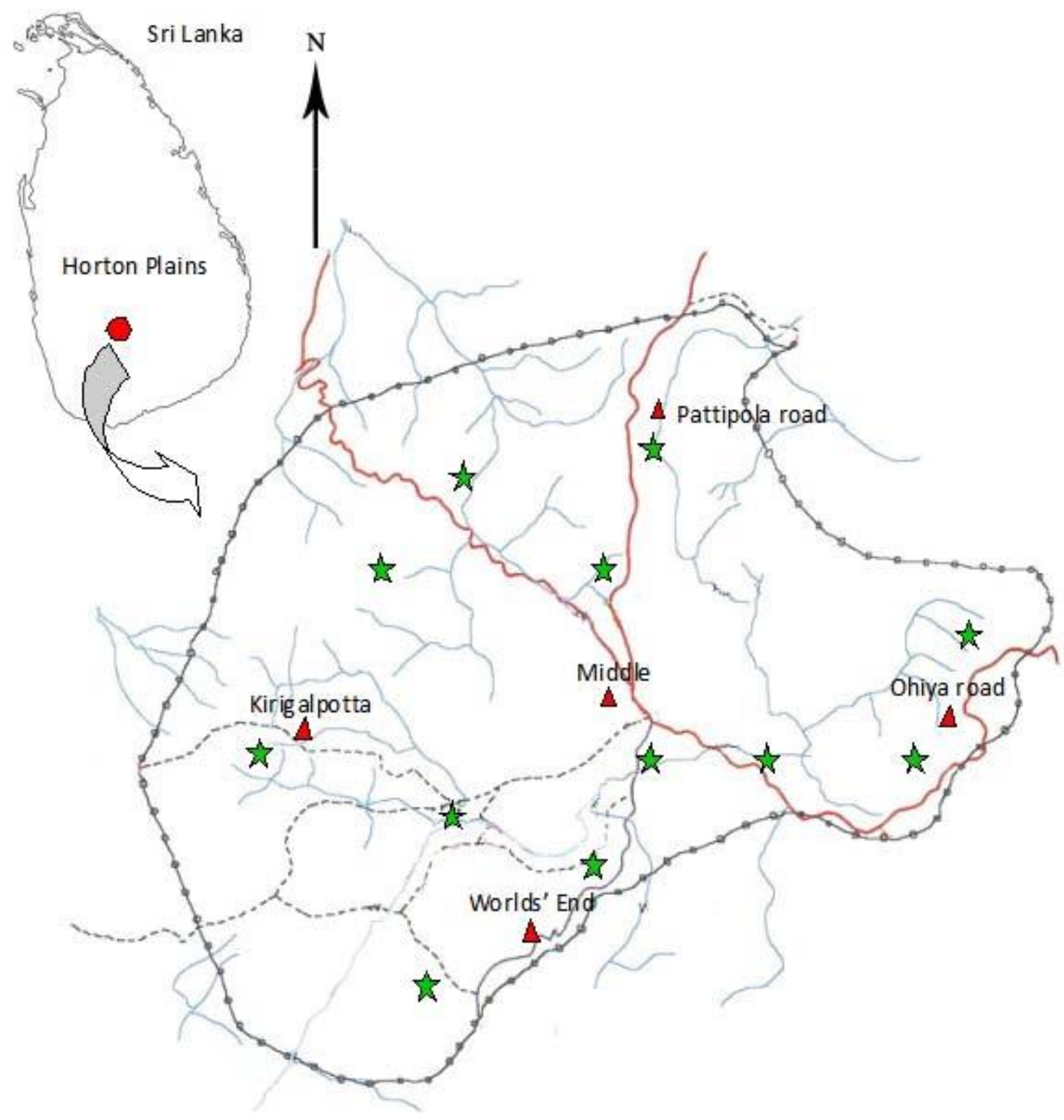

Figure 1: Map of Horton Plains National Park showing air sampling sites (red triangles) and lichen sampling sites (green stars). 


\section{Sampling sites}

Air sampling sites (5) and lichen sampling sites (12) were selected using a map of HPNP (Figure $1)$. Lichen sampling sites were situated in both continuous forest (6) and forest islands (6). All the air sampling sites were situated facing the north-west or south-east wind directions. The longitude, latitude and altitude of all the sampling sites are given in the Table 1 .

\section{Air sample storage}

After exposure, the samplers (in duplicate) were removed and sealed and taken to the laboratory for further analysis. In the laboratory, the sorbent filter was removed and sealed in a small polythene bag. These were then marked with an identifying code indicating the pollutant, site and sample number and stored at $4{ }^{\circ} \mathrm{C}$ for three days until analyses. At the same time, a set of samplers was prepared in an identical manner and kept unexposed at each sampling site to be used as controls for each pollutant type.

\section{Analysis of $\mathrm{NO}_{2}$}

Before the analysis, filters with trapped pollutants were transferred into clean glass vials $(20 \mathrm{ml})$ using Teflon covered tweezers. Pollutants were then extracted into deionized water $(5 \mathrm{ml})$ by sonicating for 10 minutes in a shaker. The same procedure was carried out to the blank. The solution was then analyzed for nitrite using a colourimetric technique (Saltzman, 1954). For the preparation of the colour reagent, phosphoric acid $(25 \mathrm{ml}$ of $85 \%$ ) and $2.5 \mathrm{~g}$ of sulfanilamide were added to $200 \mathrm{ml}$ of deionized water in a $250 \mathrm{ml}$ volumetric flask. After dissolving sulfanilamide completely, $0.25 \mathrm{~g}$ of $\mathrm{N}$ (1-napthyl)-ethylenediamine dihydrochloride was added and mixed to provide a clear solution. It was then diluted to $250 \mathrm{ml}$ with water. Then the colour reagent $(0.2 \mathrm{ml})$ was added to $5 \mathrm{ml}$ of the sample while mixing the solution. After 10 minutes, the absorbance was measured using a colourimeter (Janway-6050) at a wavelength of $540 \mathrm{~nm}$ against a blank, which was treated with the same quantities of the reagents employed for colour development. Finally, a calibration curve was obtained for solutions in the concentration ranged from 1-10 $\mathrm{ppm}$.

\section{Analysis of $\mathrm{SO}_{2}$}

A buffer solution [3 $\mathrm{g}$ of $\mathrm{MgCl}_{2} .6 \mathrm{H}_{2} \mathrm{O}, 0.5 \mathrm{~g}$ of $\mathrm{CH}_{3} \mathrm{COONa} .3 \mathrm{H}_{2} \mathrm{O}, 0.1 \mathrm{~g}$ of $\mathrm{KNO}_{3}$ and $2 \mathrm{ml}$ of acetic acid (99\%)] was made in $50 \mathrm{ml}$ of distilled water and it was made up to $100 \mathrm{ml}$. To prepare the standard sulphate solution, $0.0148 \mathrm{~g}$ anhydrous $\mathrm{Na}_{2} \mathrm{SO}_{4}$ was dissolved in deionized water and was diluted to $100 \mathrm{ml}$ in a volumetric flask. For the measurement of turbidity, the sample $(20 \mathrm{ml})$ was filtered and placed in a $25 \mathrm{ml}$ conical flask. The buffer solution $(4 \mathrm{ml})$ was added and mixed using a magnetic stirrer. To this solution, $1 \mathrm{~g}$ of $\mathrm{BaCl}_{2}$ crystals was added at once and stirred for $1 \mathrm{~min}$. The solution was poured into the cell of the turbidity meter (DRT-15CE) and the absorbance reading was taken after 5 minutes. Finally, a calibration curve was obtained for solutions in the concentration ranged from 0.5-5.0 ppm.

\section{Concentrations of absorbed pollutants}

The concentration of each pollutant was calculated in $\mathrm{nM} \mathrm{M}^{-3}$ as follows:

$\operatorname{Pollutant}(g)=\frac{L \times E_{v} \times[X]}{T \times D_{c}}$,

where, $\quad L=$ Total air resistant $\left(41.2 \mathrm{~m}^{-1}\right)$

$E_{\mathrm{v}}=$ Extraction volume $(\mathrm{ml})$

$T=$ Sampling time (s)

$D_{\mathrm{C}}=$ Diffusion coefficient $\left(\mathrm{m}^{2} \mathrm{sec}^{-1}\right)$ $D_{C}$ for $\mathrm{NO}_{2}=1.54 \times 10^{-5} \mathrm{~m}^{2} \mathrm{sec}^{-1}$ $D_{C}$ for $\mathrm{SO}_{2}=1.32 \times 10^{-5} \mathrm{~m}^{2} \mathrm{sec}^{-1}$

$[X]=$ Pollutant anion concentration $(\mu \mathrm{M})$

The resulting value from the above equation was converted to parts per billion by volume (ppbv) using the following formula.

$p=\frac{n \times R \times T}{V}$,

where, $\quad n=$ Number of moles (in $\mathrm{a} \mathrm{m}^{3}$ )

$R=$ Gas constant $\left(0.082061 \mathrm{~atm} \mathrm{~mol}^{-1} \mathrm{~K}^{-1}\right)$

$T=$ Temperature during sampling $(\mathrm{K})$

$V=$ Air volume $(1000 \mathrm{~L})$ 
Table 2: Correlation analysis results (Pearson Correlation Coefficient and p values) amongst the meteorological parameters.

\begin{tabular}{llll}
\hline Meteorological parameter & Temperature & Rainfall & Relative Humidity \\
\hline Rainfall & 0.046 & & \\
& $0.876^{\mathrm{ns}}$ & & \\
Relative Humidity & 0.743 & -0.052 & \\
& $0.002^{* *}$ & $0.860^{\mathrm{ns}}$ & \\
& & & \\
Wind Velocity & 0.040 & -0.091 & 0.004 \\
& $0.892^{\mathrm{ns}}$ & $0.757^{\mathrm{ns}}$ & $0.989^{\mathrm{ns}}$ \\
\hline
\end{tabular}

\section{Lichen collection and Identification}

Lichen distribution on one third of the trees $(\mathrm{GBH} \geq 10 \mathrm{~cm})$ present in each plot $\left(50 \times 20 \mathrm{~m}^{2}\right)$ was studied. Lichen diversity and their distribution pattern were studied by recording the presence or absence of lichens on each tree up to $2 \mathrm{~m}$ height from the ground level, using a $20 \times$ $20 \mathrm{~cm}^{2}$ grid. The lichen specimens collected were observed under the dissecting microscope for morphological characters. A cross-section of the thallus and ascomata were taken using a sharp blade prior to observe under the compound stereomicroscope. At each stage, illustrations were made as much as possible. Characters were noted according to the lichen data sheet. Finally, all the lichens were identified up to genus level according to lichen determination keys and previous literature.

\section{Index of Atmospheric Purity (IAP)}

The IAP was calculated using the occurrence and frequency of lichens at the study sites and an ecological index for each species using the formulae;

$$
I A P=\sum_{i}^{n} \frac{Q \times f}{10}
$$

where, $n$ is the number of lichen species found at a given station, $Q$ is the ecological index of a species or the average species richness and $f$ is the number of sampled trees on which this lichen species was found at the site;

The value for $Q \times f$ is divided by 10 to give a more manageable number (Johnsen and Søchting, 1973).

\section{RESULTS}

\section{Variation of meteorological data in HPNP}

The highest maximum temperature has been observed during March to April and the lowest was recorded in July. The average highest rainfall occurred during October to December and the lowest rainfall in February (Data not given). According to the correlation analysis, the mean temperature and the relative humidity were significantly correlated (Table 2).

\section{Variation of ambient $\mathrm{NO}_{2}$ concentrations}

Data used in this study for passive sampling was the average values of 15-30 days. The obtained values were further averaged in to 24 hours. As there are no standards available for the period of 15-30 days, $24 \mathrm{~h}$ values were compared with 24 h standards (WHO, 2000; 2006).

\section{Variation of ambient $\mathrm{SO}_{2}$ concentrations}

The average concentrations of $\mathrm{SO}_{2}$ during the study period (August, 2005 to September, 2006) at each sampling point showed considerable variations (Figure 2). The variation pattern of $\mathrm{SO}_{2}$ concentrations among five sampling points was also showed almost a similar trend throughout the study period. World's End showed comparatively low concentration of $\mathrm{SO}_{2}$ throughout the study period. Comparatively higher concentrations were observed during the whole period at Pattipola road and at the middle point. 
$\multimap$ Pattipola Rd. $\longrightarrow$ Ohiya Rd. $\multimap$ World's End $\multimap$ Middle $\multimap$ Kirigal potta

A

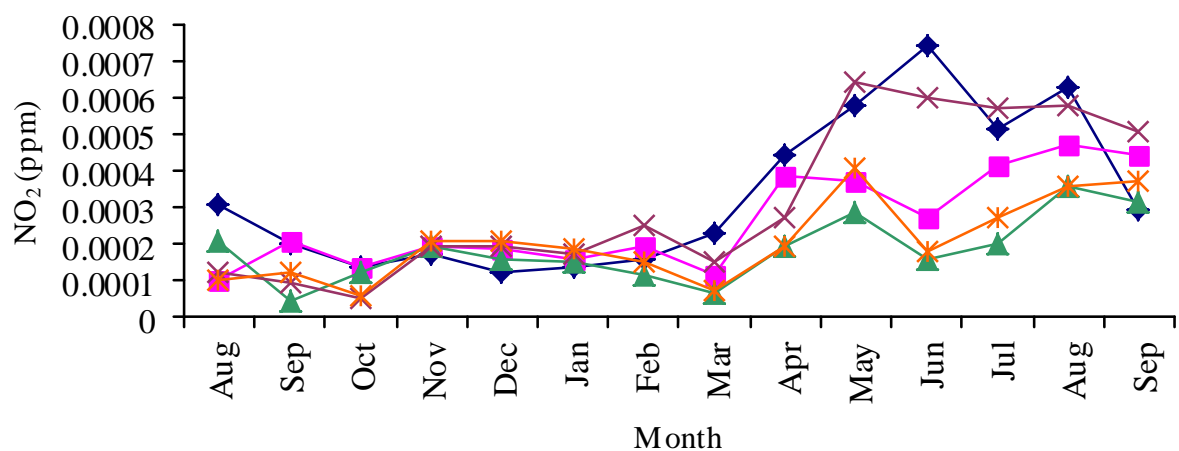

B

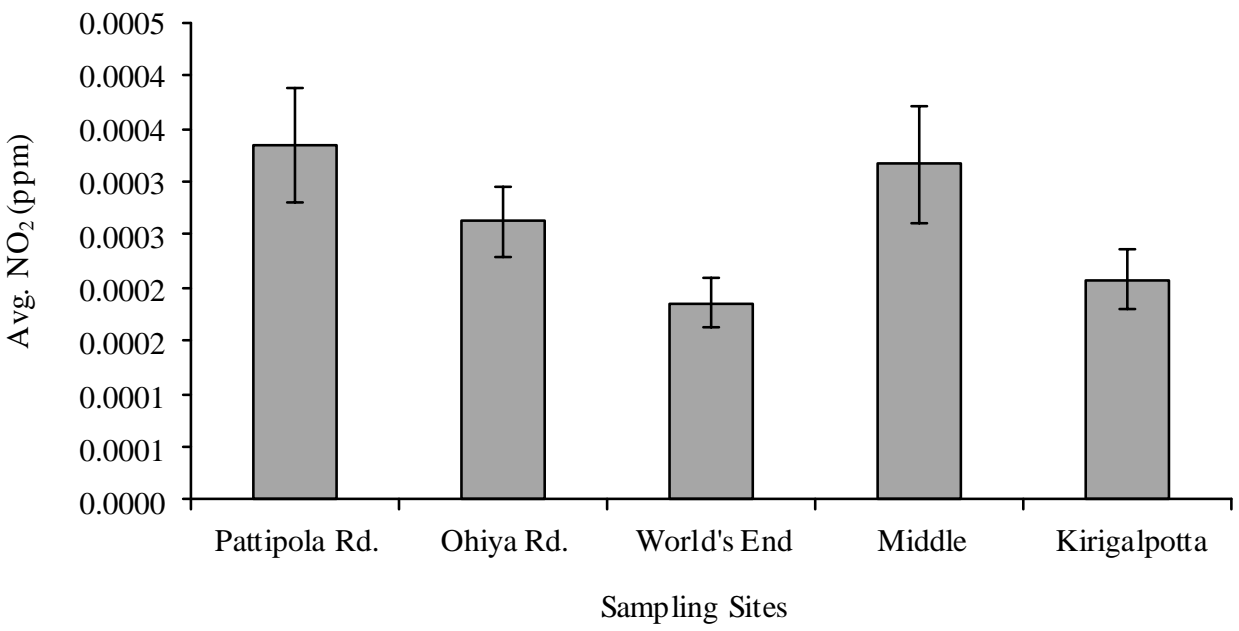

C

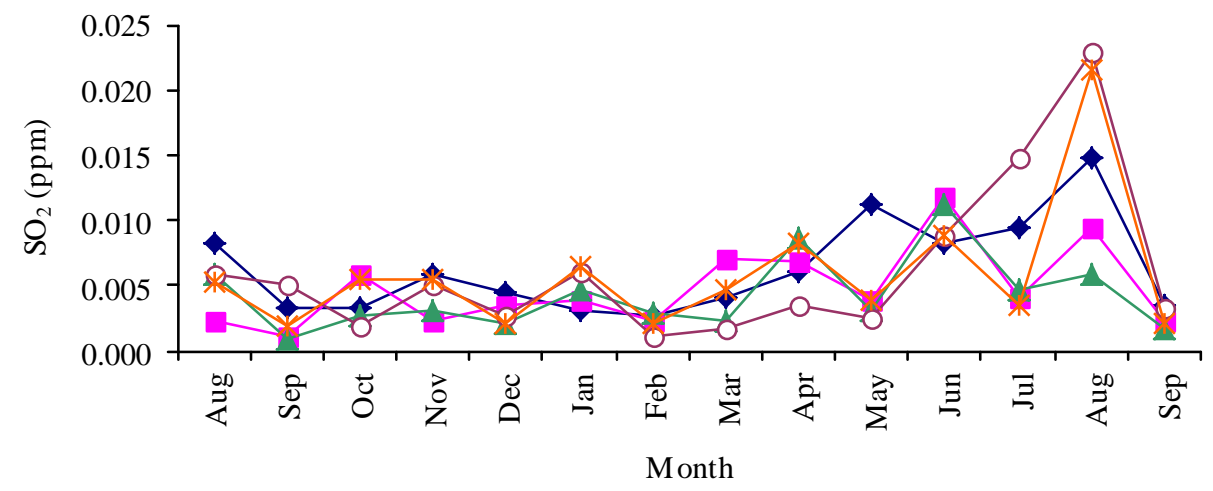

D

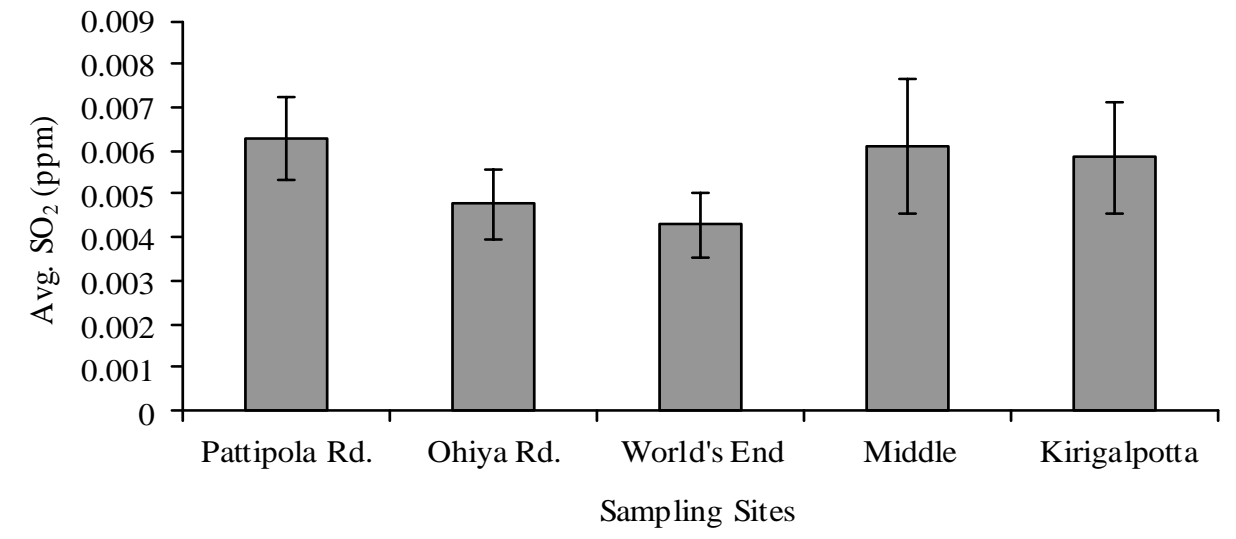

Figure 2: Variation of $24 \mathrm{~h}$ average ambient concentrations of $\mathrm{NO}_{2}(\mathrm{~A})$ and $\mathrm{SO}_{2}(\mathrm{C})$ over the period of 12 months and average concentrations of $\mathrm{NO}_{2}(\mathrm{~B})$ and $\mathrm{SO}_{2}(\mathrm{D})$ in each sampling point. 
A

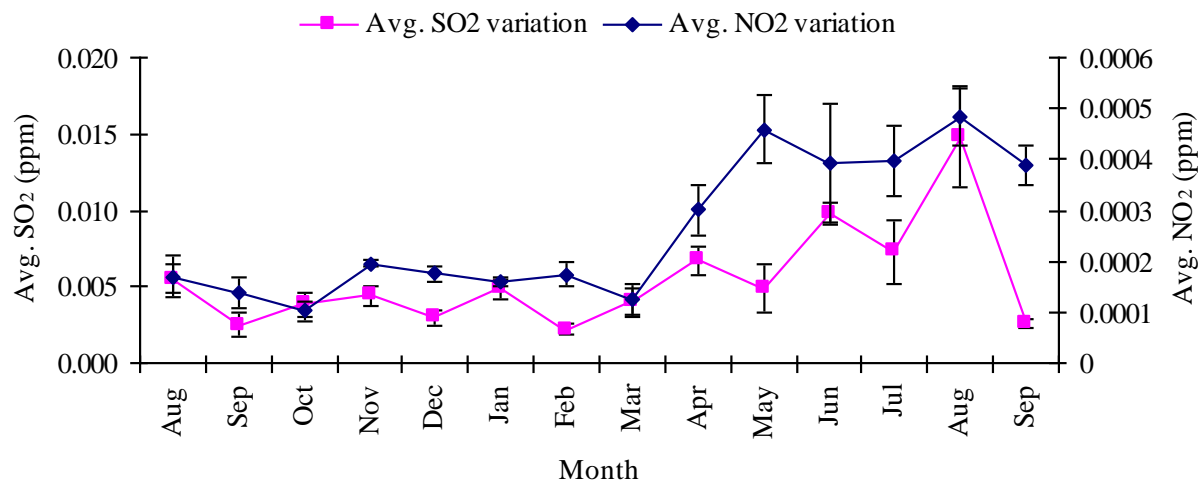

B

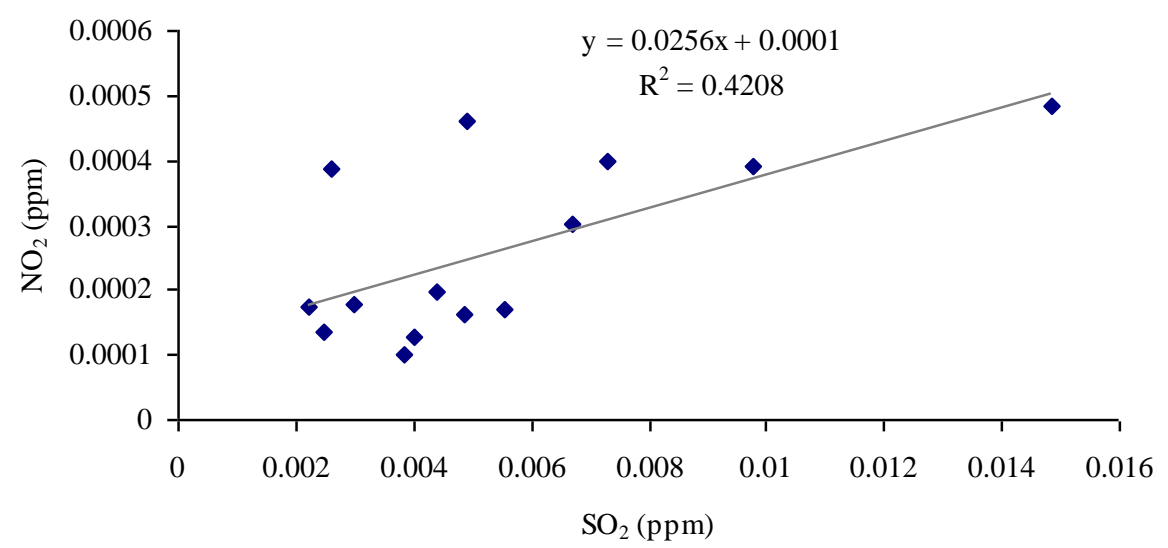

C

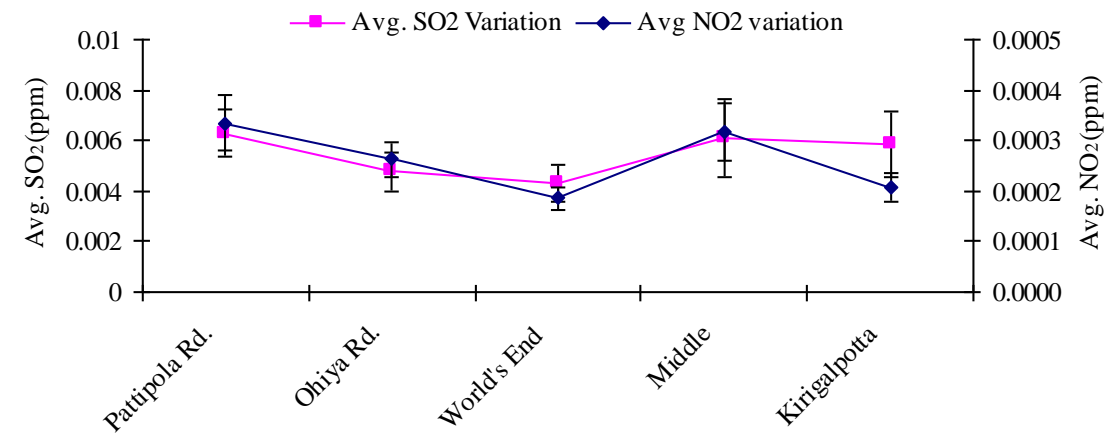

Sampling Sites

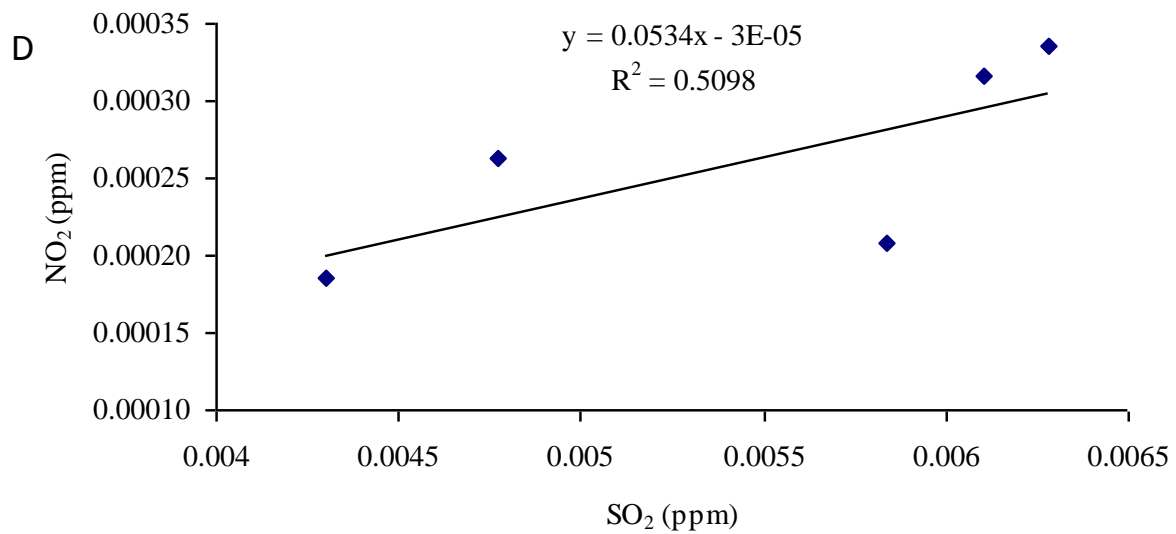

Figure 3: Monthly variations of average ambient $\mathrm{SO}_{2}$ and $\mathrm{NO}_{2}$ concentration at $\mathrm{HPNP}$ (A), their correlations (B), at each observed point (C) and their correlations (D). 
The average concentration of $\mathrm{SO}_{2}$ was comparatively low between September 2005 to March 2006 and began to increase after March 2006 till September 2006. The lowest average $\mathrm{SO}_{2}$ concentration $(0.002 \mathrm{ppm})$ was observed in February 2006 and the highest average concentration (0.014 ppm) was in August 2006 (Figure 3). The highest concentration of $\mathrm{SO}_{2}$ (0.0063 ppm) was observed at the Pattipola sampling point and the second highest value (0.0061 ppm) was observed at the Middle sampling point which was situated close to the vehicle park in HPNP. The lowest concentration of $\mathrm{SO}_{2}(0.0042 \mathrm{ppm})$ was observed at the World's end.

The variations of the average $\mathrm{NO}_{2}$ and $\mathrm{SO}_{2}$ concentrations in each month were almost similar throughout the study period with a significant positive correlation at $\mathrm{p} \leq 0.05$ (Figure 2 ). Similarly, the average concentrations of the two pollutants in each sampling site showed similar variations (Figure 3), but with an insignificant positive correlation at $\mathrm{p} \leq 0.05$.

Relative Humidity (RH) at HPNP showed values $>70 \%$ throughout the year. Lower $\mathrm{RH}$ was recorded during February to March $(<70 \%)$. The highest wind velocity was observed during June to July and the lowest was observed in April (Data not given). RH and wind velocity correlated positively but was insignificant (Table 2).

\section{Variation of ambient $\mathrm{NO}_{2}$ concentration with environmental and vehicular factors}

temperature, relative humidity, bright sunshine and the total number of vehicles visiting the HPNP are given in Figure 4. The variation of ambient $\mathrm{NO}_{2}$ concentration during the study period showed insignificant positive correlation $(\mathrm{p} \geq 0.05)$ with the rainfall pattern (Table 3 ). Similar insignificant relationship was observed between wind velocity and $\mathrm{RH}$, hours of bright sunshine and the number of vehicles visiting to HPNP. However, a positive significant correlation $(\mathrm{p} \leq 0.05)$ was observed between the ambient $\mathrm{NO}_{2}$ concentration and temperature (Table 3).

\section{Variation of ambient $\mathrm{SO}_{2}$ concentration with environmental and vehicular factors}

Variation of the ambient $\mathrm{SO}_{2}$ concentration with respect to rainfall, wind velocity, average temperature, relative humidity, bright sunshine and the number of vehicles visiting HPNP were comparable to those of the ambient $\mathrm{NO}_{2}$ concentration. However, the correlations of variations of the ambient $\mathrm{SO}_{2}$ concentration with meteorological parameters were different to those for $\mathrm{NO}_{2}$ concentrations. The ambient $\mathrm{SO}_{2}$ concentration showed a positive correlation with rainfall, wind velocity, ambient temperature, $\mathrm{RH}$ and the number of vehicles visiting HPNP during the study period. The positive correlation was higher with wind velocity and the number of vehicles visiting, while the correlation was less with rainfall, ambient temperature and $\mathrm{RH}$. However, all these correlations were insignificant at $\mathrm{p} \leq 0.05$ (Table 3). Further, ambient $\mathrm{SO}_{2}$ concentration was inversely varied with the precipitation in many months of the study period (Figure 5A). A negative but insignificant correlation was observed between the ambient $\mathrm{SO}_{2}$ concentration and bright sunshine (Table 3).

Table 3: Correlation coefficients and their $\mathrm{p}$ values between the pollutants and climatic and other parameters (bright sunshine, temperature, wind velocity, rainfall and number of vehicles).

\begin{tabular}{lccccccc}
\hline Variables & $\begin{array}{c}\mathbf{S O}_{2} \\
(\mathbf{p p m})\end{array}$ & $\begin{array}{c}\text { Rainfall } \\
(\mathbf{m m})\end{array}$ & $\begin{array}{c}\text { Wind } \\
\text { Velocity } \\
(\mathbf{k m} / \mathbf{h})\end{array}$ & $\begin{array}{c}\text { Temperature } \\
\left({ }^{\mathbf{0}} \mathbf{C}\right)\end{array}$ & $\begin{array}{c}\text { Relative } \\
\text { Humidity } \\
(\boldsymbol{\%})\end{array}$ & $\begin{array}{c}\text { Bright } \\
\text { Sunshine } \\
(\mathbf{h})\end{array}$ & $\begin{array}{c}\text { No. of } \\
\text { Vehicles }\end{array}$ \\
\hline $\mathrm{NO}_{2}$ & 0.641 & 0.158 & 0.100 & 0.566 & 0.425 & 0.192 & 0.181 \\
$(\mathrm{ppm})$ & $0.013^{*}$ & $0.590^{\mathrm{ns}}$ & $0.734^{\mathrm{ns}}$ & $0.035^{*}$ & $0.129^{\mathrm{ns}}$ & $0.511^{\mathrm{ns}}$ & $0.537^{\mathrm{ns}}$ \\
$\mathrm{SO}_{2}$ & & 0.122 & 0.382 & 0.169 & 0.056 & -0.149 & 0.448 \\
$(\mathrm{ppm})$ & - & $0.677^{\mathrm{ns}}$ & $0.178^{\mathrm{ns}}$ & $0.564^{\mathrm{ns}}$ & $0.849^{\mathrm{ns}}$ & $0.611^{\mathrm{ns}}$ & $0.108^{\mathrm{ns}}$ \\
& & & & & & & \\
\hline
\end{tabular}



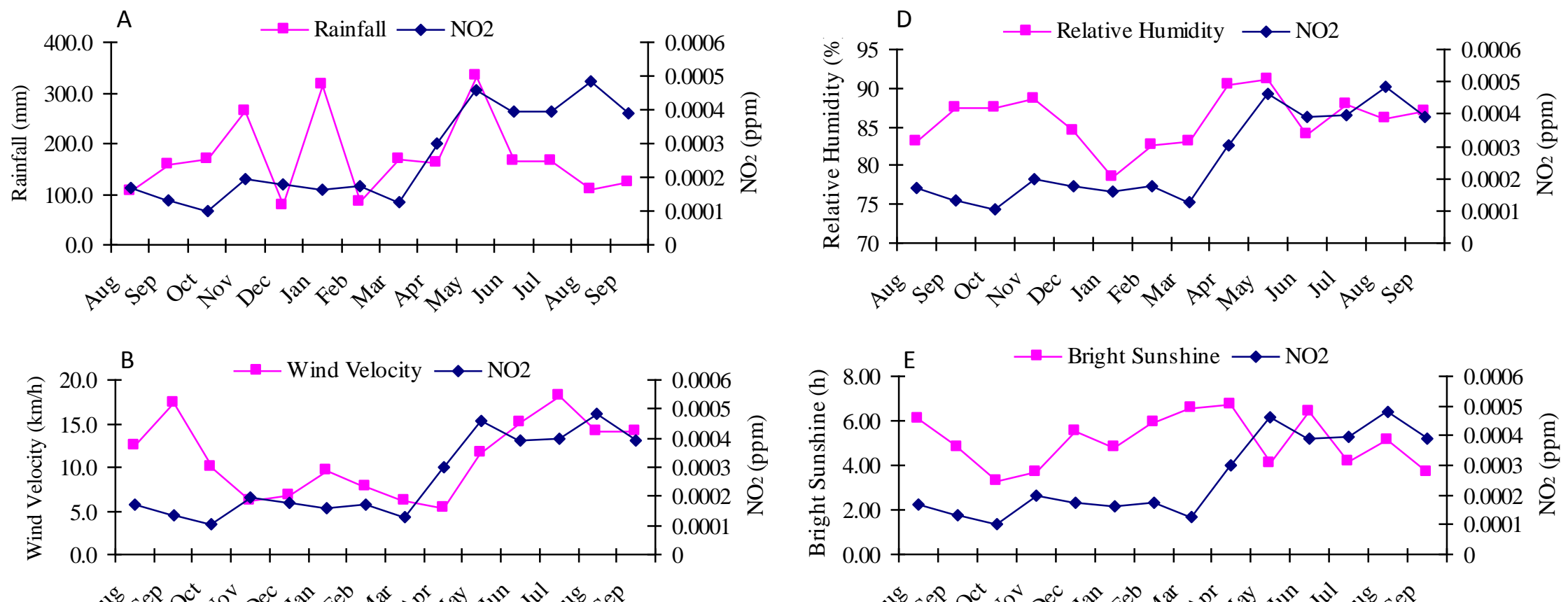

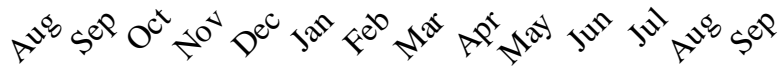

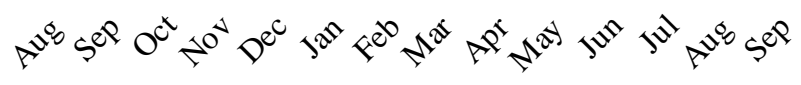

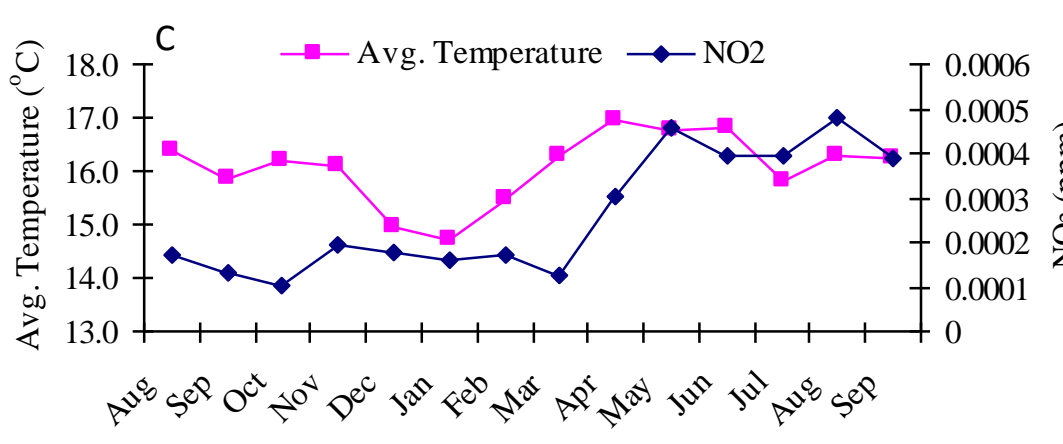

Month

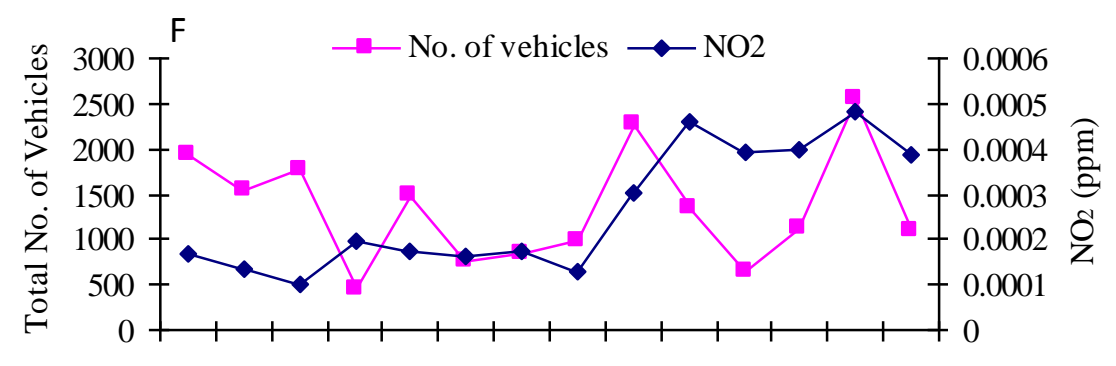

$$
\text { be }
$$

Month

Figure 4 : Variation of $\mathrm{NO}_{2}$ with rainfall (A), wind velocity (B), average temperature (C), relative humidity (D), bright sunshine (E) and total number of visited vehicles (F) in $\mathrm{HPNP}$. 
Table 4: Number of genera and taxa included in each lichen families recorded in HPNP

\begin{tabular}{lcc}
\hline Family & Genera & Species/Taxa \\
\hline Bacidiaceae & 02 & 09 \\
Chrysothricaceae & 01 & 01 \\
Cladoniaceae & 01 & 05 \\
Coccocarpiaceae & 01 & 03 \\
Collemataceae & 02 & 16 \\
Gyalectaceae & 01 & 03 \\
Lecanoraceae & 03 & 14 \\
Lobariaceae & 03 & 48 \\
Megalosporaceae & 01 & 02 \\
Nephromataceae & 01 & 01 \\
Pannariaceae & 05 & 12 \\
Parmeliaceae & 16 & 67 \\
Pertusariaceae & 02 & 18 \\
Physiaceae & 04 & 31 \\
Placynthiaceae & 01 & 01 \\
Pyrenulaceae & 05 & 29 \\
Ramalinaceae & 01 & 01 \\
Sphaerophoraceae & 01 & 04 \\
Stereocaulaceae & 02 & 03 \\
Teloschistaceae & 02 & 02 \\
Thelotremataceae & 09 & 71 \\
Porinaceae & 03 & 08 \\
Unknown & - & 30 \\
\hline
\end{tabular}

\section{Lichen taxa in the HPNP}

A total of 379 lichen taxa belonging to 67 genera and 23 families were identified during the survey (Table 4).

\section{Number of lichen species in each plot}

The distribution of lichens from the 12 plots is shown in the Figure 6 . The highest number of taxa (107) was recorded from B1 closely followed by B9 (106 taxa) and B7 (101 taxa). All these sampling sites are located in forest islands in HPNP. Considering the continuous forest of the HPNP, the highest number of lichens (89 taxa) were recorded from the plot A4, while the least (50 taxa) was recorded in A8. Some lichen species were recorded exclusively from a single sampling location. A total of 219 lichen species were confined to 10 sampling plots. The maximum number of exclusive species was recorded from B9 (34 species) followed by A4 (31 species). The lowest number was recorded from A8 (7 species).

\section{Index of Atmospheric Purity (IAP) in HPNP}

The IAP value obtained for the whole area of the HPNP was 54.22. This value was calculated using 379 lichen species spread in 12 quadrats in forest islands and continuous forest of HPNP. The IAP value for each site is given in Table 5 . The IAP varied between 21.7 and 63.7. Almost all the sites present in forest islands had relatively higher IAP values indicating that those areas have low level of $\mathrm{SO}_{2}$. 


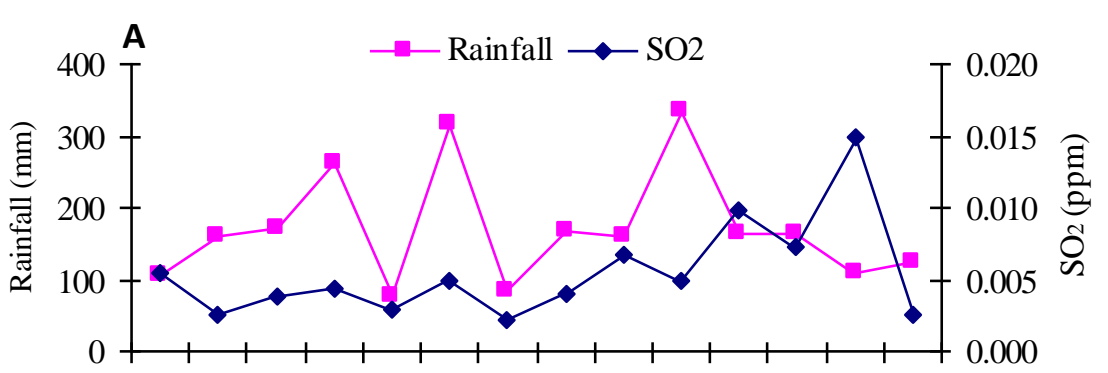

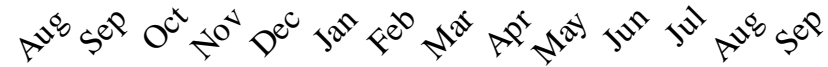

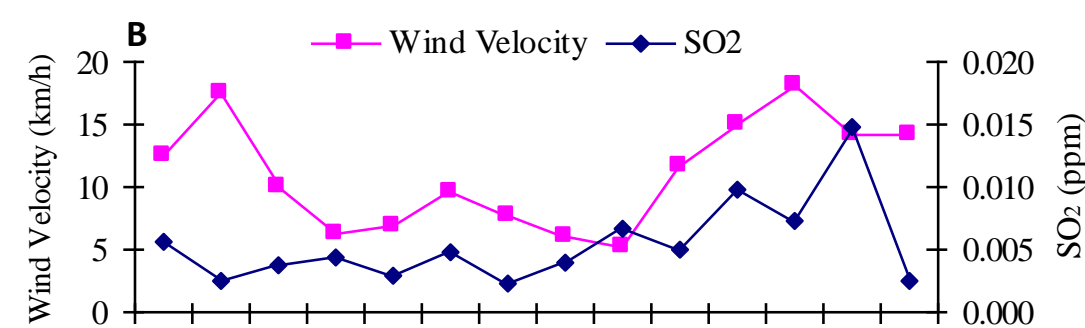

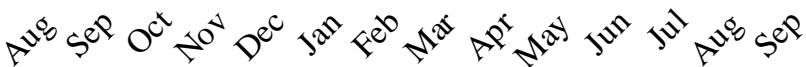

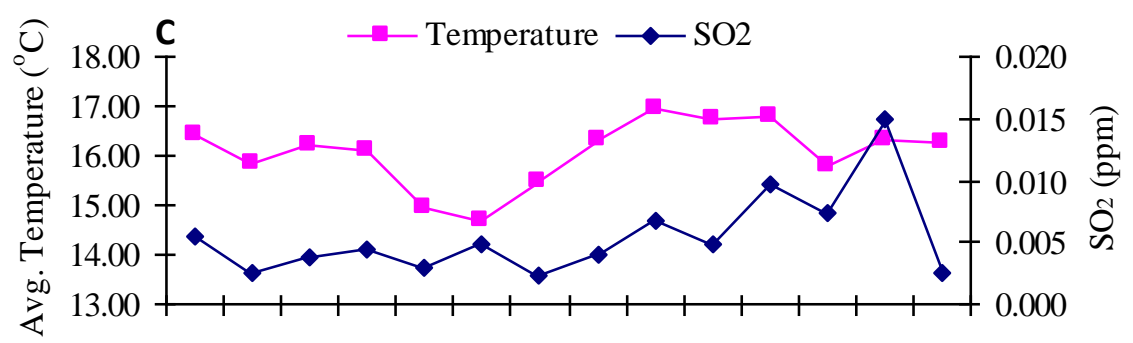

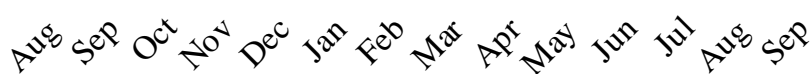

Month

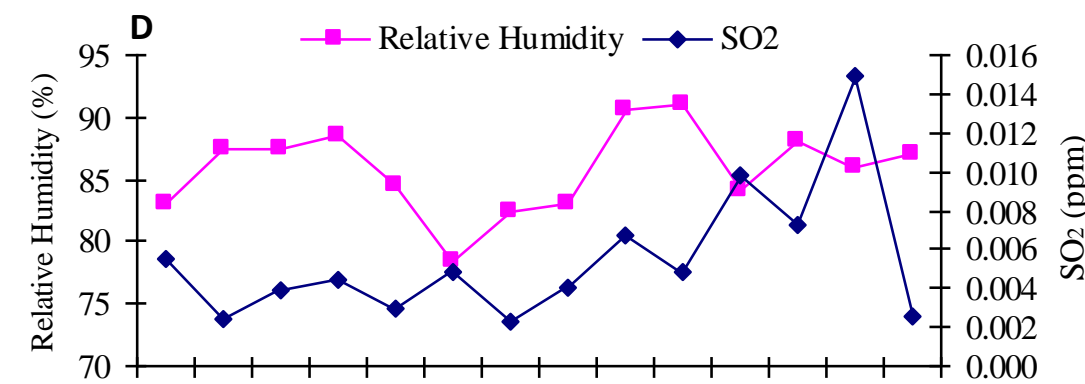

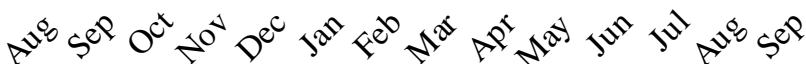

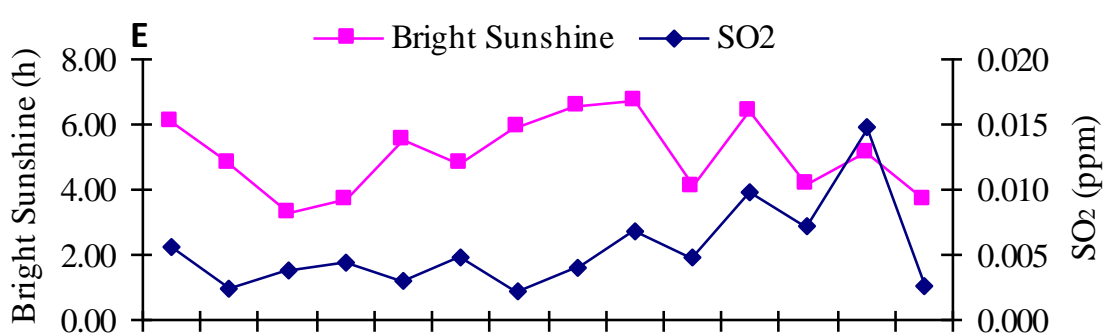

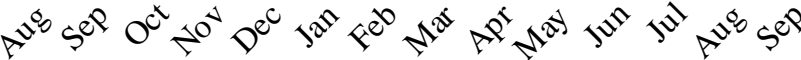

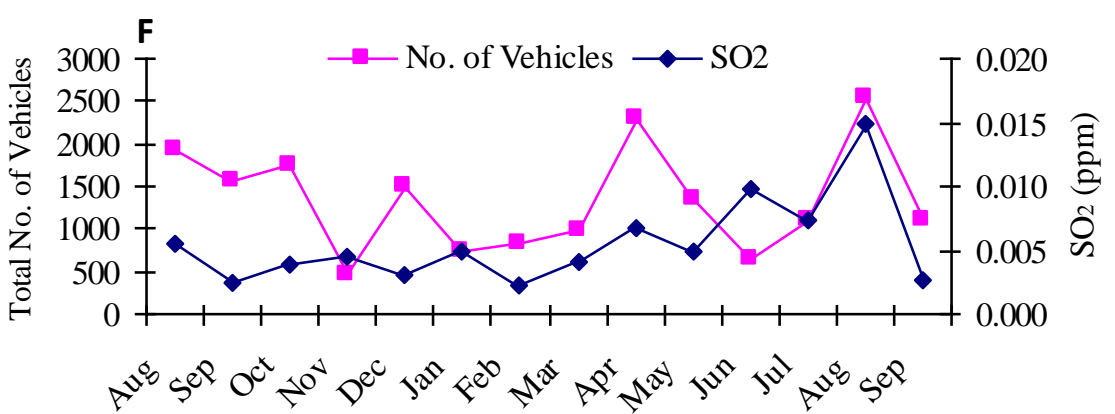

Month

Figure 5. Variation of $\mathrm{SO}_{2}$ with rainfall (A), wind velocity (B), average temperature (C), relative humidity (D), bright sunshine (E) and total number of vehicles (F) in $\mathrm{HPNP}$. 
Table 5: IAP values for each site in HPNP.

\begin{tabular}{cccccc}
\hline Site & IAP Value & SO $_{\mathbf{2}}$ Level & Site & IAP Value & SO $_{\mathbf{2}}$ Level \\
\hline A2 & 28.3 & Moderate & B1 & 58.0 & Very low \\
A3 & 58.2 & Very low & B6 & 40.7 & Low \\
A4 & 45.4 & Low & B7 & 57.0 & Very low \\
A5 & 39.3 & Low & B8 & 50.4 & Very low \\
A7 & 32.2 & Moderate & B9 & 63.7 & Very low \\
A8 & 21.7 & High & B10 & 50.5 & Very low \\
\hline
\end{tabular}

\section{DISCUSSION}

Owing to the adverse effects caused by air pollution, studies on air quality parameters are becoming important in atmospheric and environmental research today (Ghazali et al., 2009). These adverse effects have direct and indirect consequences on ecosystems and the environment. Such effects can include visible injury on vegetation and adverse impact on growth, changes in productivity, nutritive quality and community structure and biological diversity, with or without symptoms of injury to the plant foliage (Legge, 2009).

At HPNP, the average concentration of both $\mathrm{NO}_{2}$ and $\mathrm{SO}_{2}$ were comparatively low in months during September, 2005 to March, 2006 and then began to increase until September, 2006. These variations are highly correlated with the wind velocities at HPNP. Different wind velocities are due to seasonal wind patterns in Sri Lanka. Since Sri Lanka is situated close to the equator within an altitude of $6^{\circ}$ to $10^{\circ} \mathrm{N}$, it experiences a tropical climate which is somewhat modified by the seasonal wind reversal of the Asiatic monsoons. According to Domroes (1974) and Suppiah (1984) Sri Lanka and the other South Asian countries experience four climatic monsoons, namely, Southwest monsoon (MaySeptember), the first inter-monsoon (OctoberNovember), Northeast monsoon (NovemberFebruary), and the second inter-monsoon (March- May).

The lower concentrations of $\mathrm{NO}_{2}$ and $\mathrm{SO}_{2}$ were observed during the intermediate and northeast monsoonal period compared to the period during the southwest monsoonal. This could be due to relatively low wind speed experienced during inter-monsoons and north-east monsoons. During a given year, south-west winds towards the island are regular and as a result the central part of the country could also be affected due to the air pollutants coming from the more industrialized Western province. Air pollution in main cities such as Colombo and Kandy is mainly caused by increasing traffic congestions (Ileperuma, 2000). Romero et al., (1999) reported that the wind decreases pollution in some areas at Santiago in Chile. In contrast to present findings, Abeyratne (2005) reported the highest concentrations of ambient $\mathrm{NO}_{2}$ and $\mathrm{SO}_{2}$ in Kandy and Anuradhapura during north-east monsoonal period in 2001. The higher concentrations of ambient $\mathrm{NO}_{2}$ and $\mathrm{SO}_{2}$ recorded after March 2006 correlate with the number of vehicles visiting the HPNP. Festival seasons and school vacations overlap with this period and as a result a higher number of visitors and vehicles arrive at HPNP. The highest number of vehicles visiting HPNP recorded in August 2006 with the probability of increasing vehicular emissions. Similarly, Abeyratne (2005) observed sudden increases in $\mathrm{NO}_{2}$ and $\mathrm{SO}_{2}$ in Kandy during festival seasons such as Christmas, Sinhalese and Tamil New Year and Kandy Esala Perahera while reporting relatively low levels during school vacations, when the vehicular traffic was the least. Shankar (2002) in India stated that the possible reasons for increase in the levels of $\mathrm{NO}_{2}$ are due to tremendous increase in the number vehicles in the Mumbai city.

The recommended $24 \mathrm{~h}$ Sri Lankan air quality standards for $\mathrm{SO}_{2}$ and $\mathrm{NO}_{2}$ are 0.03 and 0.05 , respectively. Both $\mathrm{SO}_{2}$ and $\mathrm{NO}_{2}$ concentrations in HPNP were much lower than the standard air quality levels in Sri Lanka. A similar study carried out by Aberathne (2005), revealed that $\mathrm{NO}_{2}$ and $\mathrm{SO}_{2}$ analyzed in Kandy exceeded the recommended Sri Lankan standard by about $14 \%$ and $41 \%$ of the sampling occasions respectively. Another study carried out at Galaha junction in Peradeniya revealed that both pollutants exceeded the Sri Lankan standard on $60 \%$ of the twenty sampling occasions (Ileperuma and Dissanayake, 2004). In comparison, the average concentrations of $\mathrm{NO}_{2}$ and $\mathrm{SO}_{2}$ observed for the period of 14 months 
indicates that the air quality in HPNP is very high. However, there were no records available for the same study carried out in any national park in Sri Lanka.

Since HPNP is a remote, undisturbed forest reserve, the pollution levels could be low. However, the very low concentrations of ambient $\mathrm{NO}_{2}$ and $\mathrm{SO}_{2}$ reported in HPNP may perhaps due to the conversion of ambient $\mathrm{NO}_{2}$ and $\mathrm{SO}_{2}$ into nitric and sulfuric acid in presence of moisture, respectively (U.S. EPA report, 1998 and Martin, 1989). These acids may be deposited on the earth's surface in dry form as gases or aerosols or in wet form as acid rain. Wet deposition is determined by the amount, duration, and location of precipitation and changes in the total acid levels, which are in turn determined by atmospheric chemistry and precipitation patterns. Gunawardena and Nandasena (1998) reported that that the $\mathrm{pH}$ of rain water varied from 5.37 to 7.47 with sulphate and nitrate concentrations ranging from 0-3.39 $\mathrm{mg} / \mathrm{l}$ and $0-3.54 \mathrm{mg} / \mathrm{l}$, respectively. In the same study (Gunawardena and Nandasena, 1998), the fog had shown much higher acidities with $\mathrm{pH}$ values as low as 3.88 recorded during the dry season of April to May. All the air samples in the current study were collected inside the forest of HPNP. Hence, considerable amount of ambient $\mathrm{NO}_{2}$ and $\mathrm{SO}_{2}$ might have been taken up by the foliage of plants. Lendzian (1984) found foliar uptake of $\mathrm{SO}_{2}$ via stomata although the cuticle is impermeable to the gas. According to Rondon and Granat (1994), $\mathrm{NO}_{2}$ also enters via the cuticle of leaves without internal resistance. The lower $\mathrm{NO}_{2}$ concentrations at the HPNP might also be due to the conversion process, in which ambient $\mathrm{NO}_{2}$ converts into $\mathrm{O}_{3}$ in the presence of sunlight (Ghazali et al., 2009). In addition to individual effects, a combination of above factors may also have contributed to the low levels of $\mathrm{NO}_{2}$ and $\mathrm{SO}_{2}$ at HPNP.

The average concentrations of $\mathrm{NO}_{2}$ and $\mathrm{SO}_{2}$ between sampling points showed considerable variations in the present study. The highest ambient concentrations of both $\mathrm{NO}_{2}$ and $\mathrm{SO}_{2}$ at Pattipola, which is situated in a hilly terrain close to a main road. The main entrance of the HPNP is situated along the Pattipola road with more than $90 \%$ of vehicles arriving in HPNP. Moreover, this area directly faces Nuwara Eliya and Pattipola, where large-scale livestock farms are situated. Livestock farms generate large amount of organic waste and through anaerobic decomposition it generates ammonia and hydrogen sulphide $\left(\mathrm{H}_{2} \mathrm{~S}\right)$ (Ileperuma, 2000). $\mathrm{H}_{2} \mathrm{~S}$ oxidizes to form $\mathrm{SO}_{2}$ rapidly under atmospheric conditions (FinlaysonPitts and Pitts, 1986; Jacobson, 1999). This could have contributed to high levels of $\mathrm{SO}_{2}$ at Pattipola. The middle sampling point which was situated very close to the vehicle park at HPNP showed the highest concentrations of pollutants. Abeyratne (2005) also mentioned that the sampling sites closer to city centers recorded higher pollutant levels.

The lowest ambient $\mathrm{NO}_{2}$ and $\mathrm{SO}_{2}$ were recorded at the World's End sampling point, which faces directly towards the windward direction. High speed winds are able to carry pollutants away and perhaps account for the low pollutant concentrations in the present study. Çelik and Kadi (2007) showed that pollutants can accumulate due to slow wind speeds at high hills and mountains in a study carried out in Turkey. Furthermore, Ileperuma (2000) reported that calm weather conditions in valleys make the air quality very poor. At Kirigalpotta, where the sampling point was situated at the base of the mountain, showed higher concentrations of ambient $\mathrm{NO}_{2}$ and $\mathrm{SO}_{2}$ than in the World's End but lower than Pattipola and Middle point concentrations. The medium pollutant concentrations at Kirigalpotta site may be due to wind break effect of the Kirigalpotta Mountain. Penner et al. (1989) and Robinson (1989) have shown that the atmospheric chemical reactions were influenced by local weather patterns such as temperature, precipitation, clouds, atmospheric water vapor, wind speed, and wind direction. The variations of ambient $\mathrm{NO}_{2}$ and $\mathrm{SO}_{2}$ concentrations during the study period showed insignificant positive correlation with the rainfall pattern. Abeyratne (2005) observed a lower concentration of $\mathrm{NO}_{2}$ and $\mathrm{SO}_{2}$ during high rainfall periods, perhaps due to dissolving the gases in rainwater. A positive significant correlation was observed between the ambient $\mathrm{NO}_{2}$ concentration and temperature, but not with $\mathrm{SO}_{2}$ concentration. In contrast, Salem et al. (2009) have found an insignificant positive correlation between temperature and $\mathrm{NO}_{2}$ concentrations and a significant positive effect with $\mathrm{SO}_{2}$ concentration. Çelik and Kadi (2007) also reported that $\mathrm{SO}_{2}$ concentration increased with temperature at Karabük City in Turkey. Abeyratne (2005) found a negative relationship 
between $\mathrm{NO}_{2}$ concentration and ambient temperature only.

Considering the variations of the pollutants with relative humidity and number of vehicles visiting HPNP, both pollutants had insignificant positive correlation. According to SánchezCcoyllo and Andrade (2002), high values of pollution concentrations prevail due to weak ventilation, low relative humidity and an absence of precipitation. However, bright sunshine hours were positively and significantly correlated with $\mathrm{t}$ ambient $\mathrm{NO}_{2}$ concentrations and negatively with $\mathrm{SO}_{2}$ concentrations. Although the ambient $\mathrm{NO}_{2}$ and hours of bright sunshine were positively correlated with each other in the current study, Logan et al., (1981); Thompson (1992) and Ghazali et al., (2009) have shown that a considerable amount of $\mathrm{NO}_{2}$ is converted to $\mathrm{O}_{3}$ through photochemical reactions in the presence of sunlight. Similarly, the same correlation was observed by Trebs et al. in 2009.

The diversity and abundance of lichens are considered as indicators of environmental quality, where high values correspond to good air quality (Asta et al., 2002a, 2002b). In addition to the air quality, a combination of bark $\mathrm{pH}$, light, humidity, tree diameter, tree height and distribution is important in determining the richness of lichens (Kotelko et al, 2008). The results of the present study showed that forest islands are highly diverse compared to the continuous forest. However, evenness values were lower in forest islands than that of continuous forests.

The IAP value obtained for the whole area of the HPNP was 54.22. This value belonged to the quality level 5 indicating a 'very low' level of $\mathrm{SO}_{2}$. This value was calculated using 379 lichen species spread in 12 quadrats situated in forest islands and continuous forests at HPNP. However, IAP values calculated were different in each quadrat in HPNP. Relatively low IAP values were obtained from quadrats placed in continuous forests than that in forest islands, indicating relatively higher levels of $\mathrm{SO}_{2}$ in continuous forests (Pattipola and Middle points) than that of forest islands (Ohiya road and Kirigalpotta points). IAP values have provides a quantitative measure of the differences in richness and diversity of lichen communities influenced by activities such as habitat disturbances and urbanization (DeSloover and Leblanc, 1968; Kricke and Loppi, 2002). According to Ruoss and Vonarburg (1995) and van Dobben and ter Braak (1998) many lichen species respond negatively to high $\mathrm{SO}_{2}$ concentrations while the direct effects of $\mathrm{O}_{3}$ and $\mathrm{NO}_{2}$ on lichen communities are not well understood. However, Fuentes and Rowe (1998) observed no consistent relationship between IAP and $\mathrm{SO}_{2}$ concentration, but a reliable relationship with $\mathrm{SO}_{2}$. However, van Dobben et al., (2001) stated that, atmospheric $\mathrm{SO}_{2}$ and $\mathrm{NO}_{2}$ concentrations are the most important factors in determining the lichen biodiversity

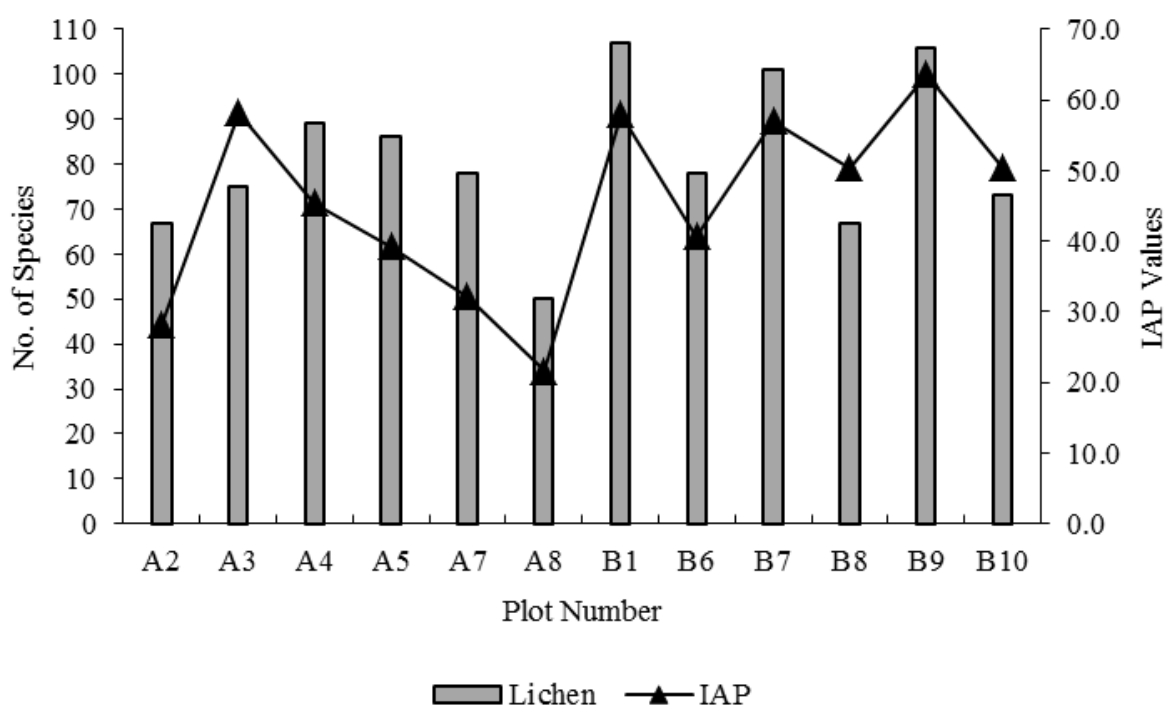

Figure 6: Number of lichen species recorded in each plots and their correspondent IAP values at the HPNP. 


\section{CONCLUSION}

Though several studies have been carried to evaluate air quality using passive gas sampling technique in Sri Lanka, this was the first study to correlate the air quality and the lichen diversity in a National Park. In the present study, a total of 379 lichen taxa were recorded and they were used to calculate IAP. The resulting higher IAP value significantly correlated with the very low level of $\mathrm{SO}_{2}$ concentration of the ambient air quality of the HPNP. These results were further confirmed by the data of passive gas sampling, in which very low levels of the ambient $\mathrm{SO}_{2}$ and $\mathrm{NO}_{2}$ concentrations were recorded. .

\section{ACKNOWLEDGEMENTS}

This study was supported by grants from National Science Foundation Sri Lanka (Grant Nos. RG/2004/BM/01 \& RG/2008/EB/02). Authors would like to thank Department of Wildlife Conservation, Sri Lanka for granting permission to carry out the survey.

\section{REFERENCES}

Abeyratne, V.D.K. (2005). Monitoring air quality using low cost techniques and assessing the impact of air pollution on vegetative crops. Ph.D Thesis, University of Peradeniya. 36-37.

Asta, J., Erhardt, W., Ferretti, M., Fornasier, F., Kirschbaum, U., Nimis, P.L., Purvis, O.W., Pirintsos, S., Scheidegger, C., Van Haluwyn, C. and Wirth, V. (2002a). Mapping lichen diversity as an indicator of environmental quality. In Monitoring with lichens monitoring lichens, NATO Science Series, IV, Vol. 7, ed. P.L. Nimis, C. Scheidegger and P.A. Wolseley, Dordrecht. Kluwer Academic Publishers, 271-279.

Asta, J., Erhardt, W., Ferretti, M., Fornasier, F., Kirschbaum, U., Nimis, P.L., Purvis, O.W., Pirintsos, S., Scheidegger, C., Van Haluwyn, C. and Wirth, V. (2002b). European guideline for mapping lichen diversity as an indicator of environmental stress. London. The British Lichen Society. pp. 273-279. In: Nimis, P.L., Scheidegger, C. \& Wolseley, P.A. (eds), Monitoring with Lichens - Monitoring Lichens, Kluwer Academic Publishers, Dordrecht, Boston, London.

Brown, D.H. (1984). Uptake of mineral elements and their uses in pollution monitoring. In Experimental Biology of Bryophytes, eds. A.F. Dyer and J.G. Duckett, 229255.

Çelik, M.B. and Kadi, I. (2007). The relation between meteorological factors and pollutants concentrations in Karabük city. G.U. Journal of Science 20 (4): 87-95.

DeSloover, J., and Leblanc, F. (1968). Mapping of atmospheric pollution on the basis of lichen sensitivity. In Proceedings of the symposium in recent advances in tropical ecology. Eds. R. Misra, and B. Gopal.
International society for tropical ecology. Banaras Hindu University, Varanasi, India, 42-56.

Domroes, M. (1974). The Agroclimate of Ceylon, a contribution towards the ecology of tropical crops. Franz Steiner, Wiesbaden, P. 265.

Finlayson-Pitts, B.J. and Pitts, J.N. (1986). Atmospheric chemistry, Fundamentals and Experimental techniques. John Wiley and Sons, Inc., New York, 1098.

Fuentes, J.M.C. and Rowe, J.G. (1998). The effect of air pollution from nitrogen dioxide on epiphytic lichens in Seville, Spain. Aerobiologia 14: 241-247.

Garty, J. and Hagemeyer, J. (1988). Heavy metals in the lichen Ramalina duriaei transplanted at biomonitoring stations in the region of a coal-fired power plant in Israel after 3 years of operation. Water, Air and Soil Pollution 38 ( 3 \& 4): 311-323.

Ghazali, N.A., Ramli, N.A., Yahaya, A.S., Yusof, N.F., Sansuddin, N. and Madhoun, W.A.L. (2009). Transformation of nitrogen dioxide into ozone and prediction of ozone concentrations using multiple linear regression techniques. Environmental Monitoring and Assessment, 165(1-4): 475-489. DOI: 10.1007/s10661-009-0866-0.

Green, M.J.B. (1990). IUCN directory of South Asian protected areas. IUCN-The World Conservation Union, Cambridge, U.K., Pp. 1-324.

Gunawardena, E.R.N. and Nandasena, K.A. (1998). Monitoring of acid rain/fog in a cloud forest at Horton Plains in Sri Lanka. In, Proceedings of the Workshop on Acid Rain Monitoring and Air Quality Modeling, ed. O.A. Ileperuma, 43-49.

Gunawardena, E.R.N., Rajapakshe, U., Nandasena, K.A. and Rosier, P.T. (1998). Water quality issues in the uplands of Sri Lanka. University of Peradeniya-Oxford forestry Institute link project, 37-44.

Hale, M.E. (1981). A revision of the lichen family Thelotremataceae in Sri Lanka. Bulletin of the British Museum (Natural History), Botany Series 8: 227-332.

Ileperuma, O.A. (2000). Environmental pollution in Sri Lanka, A review. Journal of National Science Foundation Sri Lanka 28 (4): 301-325.

Ileperuma, O.A. and Abeyratne, V.D.K. (2001). Development of passive gas sampling techniques to monitor air pollution levels in cities of the third world; A case study from Sri Lanka. Analytical Science 17 supplement, a291-a293.

Ileperuma, O.A. and Dissanayake, S. (2004). Monitoring air quality at Galaha junction using active and passive sampling techniques. Proceedings of the Peradeniya University Research Sessions, Peradeniya, Sri Lanka 9: 154.

Jacobson, M.Z. (1999). Fundamentals of atmospheric modeling. Cambridge University Press, Cambridge, 656.

James, P.W. (1973). The effect of air pollutants other than hydrogen fluoride and sulphur dioxide on lichens. In Air Pollution and Lichens, ed. B.W. Ferry, M.S. Baddeley and D.L. Hawksworth, 143-176.

Jayalal, R.G.U., Wijesundara, D.S.A. and Karunaratne, V. (2008). Lichenological works in Sri Lanka. $13^{\text {th }}$ International Forestry and Environment Symposium , Pp.69-70.

Jayalal R.G.U., Wolseley P.A., Gueidan C., Aptroot A., Wijesundara D.S.A. and Karunaratne V. (2012). Anzia 
mahaeliyensis and Anzia flavotenuis, two new species from Sri Lanka. The Lichenologist 44(3): 381-389.

Jayalal, R.G.U., Illeperuma, O.A., Wijesundara, D.S.A. and Karunaratne, V. (2006). Monitoring air pollution levels in the Horton Plains National Park using passive gas sampling technique. Sri Lanka Association for the Advancement of Science. Proceeding of the $62^{\text {nd }}$ Annual Sessions. Pp. 124.

Jayalal, U., Oh, S.O., Park, J.S., Sung, J.H., Kim, S.H. and Hur, J.S. (2015). Evaluation of air quality using lichens in three different types of forest in Korea. Forest Science and Technology 12 (1): 1-8.

Jayasinghe, S., Siriwardhana, A.S. and Karunaratne, V. (2015). Natural iron sequestering agents: their roles in nature and therapeutic potential. International Journal of Pharmacy and Pharmaceutical Science 7 (9): 8-12.

Johnsen, I., and Søchting, U. (1973). Air pollution influence upon the epiphytic lichen vegetation and bark properties of deciduous trees in the Copenhagen area. Oikos 24: 344-351.

Kathirgamanathar S., Ratnasooriya W.D., Baekstrom P., Andersen R.J. and Karunaratne V. (2006). Chemistry and Bioactivity of Physciaceae Lichens Pyxine consocians and Heterodermia leucomelos. Pharmaceutical Biology (Formerly International Journal of Pharmacognosy) 44(3): 217-220.

Karunaratne, V., Hoveyda, H.R. and Orvig, C. (1992). General method for the synthesis of Trishydroxamic acids. Tetrahedron Lett., 33: 1827.

Karunaratne, V., Bombuwala, K., Kathirgamanathar, S. and Thadani, V. (2005). Lichens: A chemically important biota. J. Natn. Sci. Foundation Sri Lanka 33(3): 169186.

Kotelko, R., Doering, $\mathrm{M}$ and Piercey-Normore, M.D. (2008). Species diversity and genetic variation of terrestrial lichens and bryophytes in a boreal jack pine forest of Central Canada. The Bryologist 111(4): 594606.

Kricke, R. and Loppi, S. (2002). Bioindication, The IAP approach. In Monitoring with lichens-Monitoring lichens, ed. P.L. Nimis, C. Scheidegger, and P.A.Wolseley. Kluwer Academic Publishers, The Netherlands, 21-37.

Legge, A.H. (2009). Air quality and ecological impacts, relating sources to effects. In Developments in Environmental Science, Vol. 91, ed. Allan H. Legge, Elsevier Ltd. Introduction, 1-19.

Lendzian, K.L. (1984). Permeability of plant cuticles to gaseous air pollutants. In, Gaseous air pollutants and plant metabolism, ed. M.J. Koziol, and F.R. Whatley, Butterworths, London, UK, 77-81.

Logan, J.A., Prather, M.J., Wofsy, S.C. and McElroy, M. B. (1981). Tropospheric chemistry - A global perspective. Journal of Geophysical Research 86: 7210-7254.

Mulgrew, A. and Williams, P. (2000). Biomonitoring of air quality using plants. Air Hygiene Report No. 10, MARC, Kings College, London, Chapter 1.

Martin, H.C. (1989). The linkages between climate change and acid rain. In, Global Climate Change Linkages, Acid Rain, Air Quality, and Stratospheric Ozone, eds. J.C. White, W .Wagner and C.N. Beale, New York, Elsevier.

Nieboer, E. and Richardson, D.H.S. (1981). Atmospheric pollution in natural water (Ann Arbor Science Publications, New York).
Nimis, P.L., Scheidegger, C. and Wolseley, P.A. (eds.) (2002). Monitoring with Lichens-Monitoring Lichens. NATO Science Series. IV. Earth and Environmental Sciences, pp. 7-10. Kluwer Academic Publishers, Dordrecht, The Netherlands.

Nylander, W. (1866). Prodromi Lichenographiae Scandinaviae Sulementia. Lichenes Laoniae Orientalis. Not. Sallsk. F. FI. fenn. Forhadl. (nova ser), 5: 99-152.

Olmez, I., Gulovali, M. and Gordon, G. (1985). Trace element concentrations in lichens near a coal-fired power plant. Atmospheric Environment 10: 1663-1669.

Orange, A., Wolseley P., Karunaratne V. and Bombuwela K. (2001). Two leprarioid lichens new to Sri Lanka. Bibliotheca Lichenologica 78: 327-333.

Penner, J.E., Connell, P.S., Wuebbles, D.J. and Covey, C.C. (1989). Climate change and its interactions with air chemistry: perspective and research needs. In: The potential effects of global climate change on the United States (Smith, J,B. and Tirpak, D,A, Eds). EPA/23005-89-050. USEPA, Office of Policy, Planning and Evaluation, Washington, DC 1989.

Robinson, P. (1989). The effects of climate change. In Global Climate Change Linkages, Acid Rain, Air Quality, and Stratospheric Ozone, eds. J.C. White, W. Wagner and C.N. Beale. New York, Elsevier.

Romero, H., Ihl, M., Rivera, A., Zalazor, P. and Azacar, P. (1999). Rapid urban growth, land-use changes and air pollution in Santiago, Chile. Atmospheric Environment 33: 4039-4047.

Rondon, A. and Granat, L. (1994). Studies on the dry deposition of $\mathrm{NO}_{2}$ to coniferous species at low $\mathrm{NO}_{2}$ concentrations. Tellus Series B 46(5): 339-352.

Ruoss, E., and Vonarburg, C. (1995). Lichen diversity and ozone impact in rural areas of Central Switzerland. Cryptogamic Botany 5: 252-263.

Salem, A.A., Soliman, A.A. and El-Haty, I.A. (2009). Determination of nitrogen dioxide, sulfur dioxide, ozone, and ammonia in ambient air using the passive sampling method associated with ion chromatographic and potentiometric analyses. Air Qual Atmos Health 2: 133-145.

Sánchez-Ccoyllo, O. R. and Andrade, M. de F. (2002). The influence of meteorological conditions on the behavior of pollutants concentrations in Sao Paulo, Brazil. Environmental Pollution 116: 257-263.

Saltzman, B.E. (1954). Colorimetric microdetermination of nitrogen dioxide in the atmosphere. Analytical Chemistry 26 (12): 1949-1955.

Sawidis, T., Chettri, M.K., Zachariadis, G.A., Stratis, J.A. and Seaward, M.R.D. (1995). Heavy metal bioaccumulation in lichens from Macedonia in North Greece. Toxicological and Environmental Chemistry 50: $157-166$.

Seaward, M.R.D., Bylinska, E.A. and Goyal, R. (1981). Heavy metal content of Umbilicaria spp. from the Sudety region of Southwestern Poland. Oikos 36: 107113.

Shankar, P.R. and Ramarao, G. (2002). Impact of air quality on human health, a case of Mumbai City, India. IUSSP Regional Conference on Southeast Asia's Population in a Changing Asian Context, 10-13.

Suppiah, R. (1984). Rainfall variations of Sri Lanka Part 1, Spatial and temporal pattern. Arch Met Geoph Biocl Ser B 34: 329-340. 
Thadhani, V., Choudhary I.M., Ali, S. and V. Karunaratne V. (2012). Antioxidant Activity of some Lichen metabolites. Natural Products Research 25(19):182737. doi: 10.1080/14786419.2010.529546.

Thompson, A.M. (1992). The oxidizing capacity of the Earth's atmosphere, Probable past and future changes. Science 256: 1157-1165.

U.S. EPA. National Air Quality and Emissions Trends Report (1997). Washington, DC, U.S. EPA, Office of Air Quality Planning and Standards, 1998.

Stamenkovic, S., Cvijan, M. and Arandjelovic, M. (2010). Lichens as bioindicators of air quality in Dimitrovgrad (South-Eastern Serbia). Arch. Biol. Sci., Belgrade, 62 (3): 643-648. DOI:10.2298/ABS1003643S.

Trebs, I., Bohn, B., Ammann, C., Rummel, U., Blumthaler, M., Konigstedt, R., Meixner, F., Fan, S. and Andreae, M.O. (2009). Atmospheric Measurement Techniques Relationship between the $\mathrm{NO}_{2}$ photolysis frequency and the solar global irradiance. Atmos. Meas. Tech. 2: 725-739.

Weerakoon, G, Plata, E.R., Lumbsch, T and Lücking, R. (2012). Three new species of Chapsa (lichenized Ascomycota: Ostropales: Graphidaceae) from tropical Asia. The Lichenologist 44(3): 373-379.

Wijesundara, D.S.A. (2007). Flowering plants of Horton Plains National Park. Annexture in The Diversity of Horton Plains National Park, 153-175.
Wijesundara, D. S. A. and Karunaratne, V. (2015). Third National Workshop on Lichens: over fifteen years of progress in lichen research in Sri Lanka. Journal of National Science Foundation, Sri Lanka 43 (2):195196.

World Health Organization (WHO). (2000). Guidelines for Air Quality. WHO/SDE/OEH/00.02. Geneva. Available at: http:// www.who.int/peh/.

World Health Organization (WHO). (2006). WHO Air Quality guidelines for particulate matter, ozone, nitrogen dioxide and sulfur dioxide. Global update 2005. Summary of Risk Assessment. Available at: www. who.int/phe/air/aqg2006execsum.pdf.

World Heritage Report (2010). http://whc.unesco.org/en/news/640

van Dobben, H.F., and ter Braak, C.J.F. (1998). Effects of atmospheric $\mathrm{NH}_{3}$ on epiphytic lichens in the Netherlands, The pitfalls of biological monitoring. Atmospheric Environment 32: 551-557.

van Dobben, H.F., Wolterbeek, H.T., Wamelink, G.W.W. and ter Braak, C.J.F. (2001). Relationship between epiphytic lichens, trace elements and gaseous atmospheric pollutants. Environmental Pollution 112: 163-169. 